\title{
Climate policy processes, local institutions, and adaptation actions: mechanisms of translation and influence
}

Arun Agrawal, ${ }^{1, *}$ Nicolas Perrin, ${ }^{2,3}$ Ashwini Chhatre, ${ }^{4}$ Catherine S. Benson ${ }^{1}$ and Minna Kononen ${ }^{5}$

In the article WIREs Clim Change 2012, 3:565-579. doi: 10.1002/wcc.193, the name of the first author was inadvertently misspelled. The name should read Arun Agrawal.

*Correspondence to: arunagra@umich.edu

${ }^{1}$ School of Natural Resources and Environment, University of Michigan, Ann Arbor, MI, USA

${ }^{2}$ Sustainable Development Department, World Bank, Washington DC, USA

${ }^{3}$ Europe and Central Asis Department, World Bank, Washington DC, USA

${ }^{4}$ Department of Geography, University of Illinois at UrbanaChampaign, IL, USA

${ }^{5}$ Global Environment Facility, Washington DC, USA 